\title{
THE CHANCE AND THE DIVINE PROVIDENCE. METHODOLOGICAL NOTES WITH PASCAL IN THE BACKGROUND
}

\begin{abstract}
The God of Christians is not a God who is simply the author of mathematical truths, or of the order of the elements; that is the view of heathens and Epicureans. He is not merely a God who exercises His providence over the life and fortunes of men, to bestow on those who worship Him a long and happy life. That was the portion of the Jews. But the God of Abraham, the God of Isaac, the God of Jacob, the God of Christians, is a God of love and of comfort, a God who fills the soul and heart of those whom He possesses, a God who makes them conscious of their inward wretchedness, and His infinite mercy, who unites Himself to their inmost soul, who fills it with humility and joy, with confidence and love, who renders them incapable of any other end than Himself.
\end{abstract}

Blaise Pascal, Pensées, 555

My aim will be to show that the analytic tradition in philosophy, by virtue of its attachment to scientific norms of rationality and truth, cannot come to terms with the mysterious transcendent reality that is disclosed in religious practice

Nick Trakakis, The End of Philosophy of Religion, 2

I. The issues of chance and Divine Providence appear in various places and contexts in the works not only of theologians and religious writers but also in the works of many philosophers and modern thinkers. It is present, for example, in the writings of Blaise Pascal. However, let us pose a question at the beginning: Is it

RySZARD KLESzCZ, Prof. Dr Hab., Chair of Logic and Methodology of Science in the Institute of Philosophy, University of Lodz; address for correspondence: ul. Lindleya 3/5, 90-131, Łódź, Poland; email: kleszcz@filozof.uni.lodz.pl; https://orcid.org/0000-0002-4618-6598. 
right to confront the thinker - considered by many as an irrationalist - with a serious analytical author who is, without the slightest doubt, the author of Opatrznośc Boża, wolność, przypadek. Studium z analitycznej filozofii religii? ${ }^{1}$ In this respect, I am inclined to say that it is worthwhile to confront them for several reasons. Well, first of all, let us say that the issue of Pascal's irrationalism is more debatable than many people think, or at least his comments on science and learning seem interesting and sometimes groundbreaking in relation to contemporary discussions on epistemology and philosophy of science. ${ }^{2}$ It is in the works of Pascal-inspired Pierre Duhem that we find deductionist views that reject induction and are precursory in relation to Popper. ${ }^{3}$ The French thinker and scholarly conventionalist not only rejected inductionism but also expressed a conviction that the hypothesis should be put to the test of experience and that it should be simple.

The above comments allow us to recognize that classifying Pascal as irrationalist is, at least, too hasty and clearly too simplistic, because he sometimes provides the analytical philosopher, the methodologist, the philosopher of science, with highly interesting and inspiring insights. This seems to be the case in the sphere of natural (scientific) knowledge because what can be the subject of sensual cognition and reasoning, in his opinion, does not require recourse to authority. However, going further, we can say that also other spheres, including even the sphere of religion, are not completely out of the competence of reason. Pascal explicitly states that we have three paths to religious faith, which we find in passage 245 of his Pensées:

There are three sources of belief: reason, custom, inspiration. The Christian religion, which alone has reason, does not acknowledge as her true children those who believe without inspiration. It is not that she excludes reason and custom. On the contrary,

\footnotetext{
${ }^{1}$ Dariusz ŁuKaSIEWICZ, Opatrzność Boża, wolność, przypadek. Studium z analitycznej filozofii religii (Poznań: W drodze, 2014). In my parenthetical references to this book I use DP followed by a page number.

${ }^{2} \mathrm{He}$ can be attributed, as it is sometimes done, a position close to Popperism in relation to his (Karl Popper's) criticism of inductionism. Without mentioning Pascal, Popper sees that in Pascalinspired Pierre Duhem we find deductionist views that reject induction. Regarding Pascal's achievements in the philosophy (theory) of science and epistemology, see Desmond M. CLARKE, "Pascal's philosophy of science," in The Cambridge Companion to Pascal, ed. Nicolas Hammond (Cambridge: Cambridge University Press, 2003), 102-21; Jean KHALFA, "Pascal's theory of knowledge," in The Cambridge Companion to Pascal, 122-43. I discuss this issue in more detail in Ryszard KLESZCZ, "Błażeja Pascala refleksja nad poznaniem," in Księga pamiatkowa Marianowi Przetęckiemu w darze na 90-lecie urodzin, ed. Anna Brożek and Jacek J. Jadacki (Lublin: Norbertinum, 2014), 235-52.

${ }^{3}$ There is a natural analogy between Blaise Pascal (who inspired Duhem) and his views, and the Popperian criticism of inductionism. See Karl R. POPPER, The Logic of Scientific Discovery (London-New York: Routledge Classics, 2002), part 1, para. 1; see also Thomas M. Harrington, Pascal philosophe. Une étude unitaire de la Pensée de Pascal (Paris: SEDES, 1982), 81.
} 
the mind must be opened to proofs, must be confirmed by custom, and offer itself in humbleness to inspirations, which alone can produce a true and saving effect. Ne evacuetur crux Christi. ${ }^{4}$

It can be said that in this domain, although according to Pascal supernatural support is necessary, reason is not only not excluded, but has an important role to play. These remarks by the author not only of Pensées, but also of many strictly scientific works, should not be disregarded, especially by the philosopher of religion.

This paper, however, is not intended by me to be a confrontation between the analytical thinker and Pascal, although I will sometimes refer to the latter's comments, also in an affirmative way. I assume, however, that without being an enemy of reason, he can be an object of reference, sometimes also an inspiration, for an analytical philosopher. However, the reason I refer to Pascal in the title of the article, to a certain extent, as a representative of a certain way of thinking, is a result of, above all, the assessment of the situation in contemporary analytical philosophy, including the analytical philosophy of religion, ${ }^{5}$ because I am convinced that analytical philosophy should not, without loss in connection with the reflection, isolate itself completely from thought which is not analytical. ${ }^{6}$ First of all, I agree with the contemporary Australian philosopher of religion, Nick Trakakis, that analytical philosophy cannot close itself off to other spheres of culture and ignore or disregard the achievements of other, past and present philosophical trends. Nor can it — which, by the way, it often does-limit the range of its interests. An analytical philosopher who appreciates the role of science (the natural sciences) can sometimes seek inspiration from various authors, also those, according to some, methodologically foreign by program. Let us only mention, for example, such philosophers as Elzenberg, Kierkegaard, or Pascal whom I just referred to, who make the analytical philosopher aware of other than the strictly analytical, often inspired by science, aspect of considerations. This situation also, and perhaps even above all, concerns the issue of the philosophy of religion, the subject of which is the complex phenomenon of broadly understood religion. In

${ }^{4}$ See Blaise Pascal, Pensées (New York: E. P. Dutton \& Co., 1958), 245 (Brunschvicg edition). To quote from this edition, I use the title followed by a fragment number.

${ }^{5}$ This problem is addressed by the work of Nick Trakakis, mentioned at the beginning. Although I do not share many of his opinions concerning both analytical philosophy in general and the analytical philosophy of religion in particular, his comments on the state of the analytical tradition in the philosophy of religion are worthy of a serious yet critical study. See Nick TRAKAKIS, The End of Philosophy of Religion (London-New York: Continuum, 2008), passim.

${ }^{6}$ When considering differences between analytical philosophy and the so-called continental philosophy, see Neil LEVY, "Analytic and Continental Philosophy: Explaining the Differences," Metaphilosophy 34, no. 3 (2003): 284-304, passim. 
my opinion, the clear boundaries between analytical and, let us say, continental reflection are somewhat blurred. This state of affairs can create hope for a better understanding. Nevertheless, it can also lead to a certain eclecticism which, for methodological and factual reasons, is not a desirable state. If there are no fundamental reasons for an analytical philosopher not to draw inspiration from outside the analytical "camp," then at the same time, while doing so, they must, of course, remember that as an analytical philosopher, they are bound by what is crucial for this philosophical trend, that is, care for appropriate precision and attention to argumentation.

II. My further remarks concerning the issues of chance and providence, will refer mainly to those parts of Professor Dariusz Łukasiewicz's monograph which concern, above all, probabilistic theism, that is, to selected issues of chapter 5, which can be considered central for the dissertation. I will focus special attention on metaphilosophical issues and some problems of methodological nature. This choice, also in the context of the mentioned chapters and issues, means that I do not aspire to present a comprehensive, or all the more so, a profound analysis of the discussed monograph in this paper. To accomplish such a task, it would be necessary to prepare a critical and monographic study which is not less insightful, and-more importantly at this stage - no less extensive than Łukasiewicz's work itself.

First of all, let us try to reconstruct the main metaphilosophical (metatheoretical) assumptions adopted in the monograph and indicate the objectives of the work. The identification of these assumptions and goals will allow us to assess the accuracy and effectiveness of these assumptions in the further part of the paper (including in the summary) and to evaluate them, if necessary.

1. Łukasiewicz's studies on the problem of God's providence are intended to be of a multi-faceted nature, combining theology, some data derived from special sciences and philosophical reflection, mainly anthropological and metaphysical, not forgetting existential and strictly religious aspects $(D P, 9)$. This means that the author does not want to follow, already in the beginning, the path of those who want to model their research on the philosophy of religion only on analyses modeled on science, especially with its naturalistic understanding. The analyses in this scope are meant to cover the main contemporary models of God's providence. This contemporary perspective, however, seems to require also a reference to the sphere of special sciences and theology of nature $(D P, 22-23)$. Such an approach shown by the author seems to me justified and personally close, although at the same time extremely difficult and requiring comprehensive competence and 
excellent methodological preparation. Because in my opinion, a certain openness to other spheres of culture and schools other than analytical one cannot and should not be accompanied by turning our backs on science and on what research in the special sciences provides us with.

2. The main intention and aim of the author are to conduct analyses on an ontological level. Already at the outset this raises the question of understanding ontology and research of this type. If ontology should be understood in the spirit of Roman Ingarden, then it would be an introduction to metaphysics. For him, metaphysics, as he understands it, goes beyond the scope of the investigations carried out by detailed sciences, striving for what would be the real essence of the subject. Its (metaphysics) intention would be to capture all that exists. It is therefore different from ontology which deals with the sphere of pure possibilities. Ingarden does not decide (at least initially) whether the task he sets for metaphysics is achievable with the cognitive means available to human beings. ${ }^{7}$

With regard to the issues examined by Łukasiewicz, in particular the issue of Providence/providence, ${ }^{8}$ he stresses that such metaphysics, in the case of these analyses, would be possible under certain conditions which seem (possibly) realizable post-mortem $(D P, 10)$. As a result, the possible cognitive aspirations seen in the ante mortem perspective must be limited to the ontological view, as ontology is understood by Roman Ingarden. However, in practice, the author in his work, while not forgetting the Ingardenian distinction, uses the ontology and metaphysics terms interchangeably. The reference I have made to Ingarden is not accidental, also because he is the one who addresses the problem of the relationship between philosophy and science, the issue of which, in the case of goals that Łukasiewicz sets for himself, seems to be of particular importance. ${ }^{9}$

3. The research conducted in this paper is intended to be an ontological study, not assuming any religious revelation, so it is not methodologically Anselmian, or more generally, scholastic. Therefore, the author does not follow the fides quaerens intellectum principle ( $D P, 10-11,21 \mathrm{ff}$.). On the metaphilosophical level, this approach seems to be similar to the Brentanian approach to the relations between philosophy and theology. It was Franz Brentano who expressed similar views in the second and third theses of his post-doctoral work (habilitation). ${ }^{10}$

\footnotetext{
${ }^{7}$ See Roman Ingarden, Controversy over the Existence of the World, vol. 1, trans. Arthur Szylewicz (Frankfurt am Main: Peter Lang, 2013), 60-61.

${ }^{8}$ In my opinion, the author uses two spelling variants here. He uses an upper-case P when 'Providence' refers to God, and a lower-case p when 'providence' refers to "a feature of the Divine Being."

${ }^{9}$ See Ingarden, Controversy, 1:49-61.

${ }^{10}$ Franz K. Brentano, "Die 25 habilitationsthesen (lateinisch und deutsch)," in Über die Zukunft der Philosophie, ed. Franz Brentano (Hamburg: Meiner, 1968), 136-37. This edition contains,
} 
Let us recall the following theses. The second one goes: "Philosophia et eos, qui eam principia sua a Theologia sumere volunt, et eos rejicere debet, qui, nisi sit supernaturalis revelatio, eam omnem operam perdere contendunt." It is stated here that philosophy rejects the thesis as it draws its principles from theology, thus emphasizing the methodological distinctiveness of philosophy and theology.

The third thesis: "Nihilominus verum est, sententias Theologia probatas eas esse, quae philosophis quasi stellae rectrices sint." This thesis states, in turn, that the theological theses can, however, be guidelines in the research of a philosophical nature. At the same time, however, such judgment, taken from theology, should be treated (analyzed and possibly justified) with the help of tools specific to philosophy. In my opinion, Professor Łukasiewicz understands the relationship between philosophy and theology in a way similar to that of Franz Brentano. Such an approach to the mutual relationship between these two fields seems to me not only highly justified but also worthy of scrupulous observance in such treatises.

4. If, as the work points out, the issues of probabilistic theism are important for the author, then the question arises as to whether the recognition that there is chance in the world can be reconciled with both the existence of God and His providence. This issue itself will be raised by me in the fifth point of these remarks and the next, the third chapter of the article. Staying at this point on the subject of more methodological issues, it should be said already that a positive answer to this question, as Lukasiewicz points out, would lead to the strengthening of the position of philosophical theism in his dispute with atheism, although it would not be a conclusive argument on the issue of divine existence $(D P, 12 \mathrm{ff}$.). One should agree with the author in this respect, bearing in mind at the same time that in philosophy such definitive arguments are not something very common and within this field we usually settle for demonstrating that a given position is supported by important, although not at all conclusive, arguments, or even just that a given position is not an irrational option. In the domain of the philosophy of religion, in the matter of the existence of God, one can try to show, as Alvin Plantinga sometimes does, that the belief of the existence of God is more rational, exposed to less difficulties than the position contradictory to it. ${ }^{11}$ It does not mean, of course, that this approach exhausts the catalog of possible important attitudes to

as the title indicates, a collection of post-doctoral theses in Latin and German language versions.

${ }^{11}$ See what Plantinga says in his God and Analogy: "I began this study by asking whether belief in the existence of God is rational. The natural theologian's answer, it turned out, is of dubious worth at best. The teleological argument is perhaps his most powerful weapon; and yet it suffers from a crucial and crippling deficiency. But if the answer of the natural theologian does not carry conviction, that of natural atheologian is even less satisfactory," as cited in James F. SENNETT, The Analytic Theist. An Alvin Plantinga Reader (Grand Rapids, MI: Eerdmans, 1998), 19. 
the issue, but only that sometimes within the sphere of philosophy we are content to point out arguments of such limited power. Then, we consider that in relation to a given dispute, this is, in some context, an answer, perhaps a temporary one, but nevertheless sufficient.

5. The above question about the possibility of reconciling the existence of chance with the existence of Divine Providence leads to several specific issues. This applies in particular to the following problems:

a) the question what is the relation between the doctrine of probabilism and orthodox Christianity, whose credo we find in the documents of the Catholic Church and post-reformation churches;

b) the existence of serious reasons to assume that the doctrine of Providence of the almighty and all-knowing God has strong biblical and patristic foundations;

c) we are also seriously justified in assuming that the basic concepts of God's providence, that is, the Anselmian and Thomistic models, are those in which the existence of events beyond God's knowledge and control is rejected;

d) in the above situation, determined by points a), b), and c), the problem of the possibility of God's co-existence and chance must be dealt with, with strong doubts of philosophical, theological and biblical nature in this respect;

e) at the same time, the current context of this discussion requires taking into account the fact that today we are dealing with different models of God's providence, with different hermeneutics of the biblical message, which at least makes it necessary to include them when considering our issues;

f) the context e) and the contemporary cognitive situation make it necessary to include the image of the world created by detailed (natural) sciences in the conducted analyses. This is necessary if only to avoid the accusation of conflict or even inconsistency with science, which seems to be important in the perspective of discussion with atheism $(D P, 21)$. The $\mathrm{f})$ thesis seems justified to me and I fully sympathize with such a vision, postulating to include the achievements of science and the so-called scientific image of the world in debates in the philosophy domain, including the philosophy of religion. Like Professor Łukasiewicz, I believe it is reasonable, or even necessary, to use the arsenal of tools from the sphere of science and theology of science when analyzing the dispute between theism and atheism. What is more, the discussion of naturalism vs. anti-naturalism also makes it necessary for the philosopher to reach for the tools of contemporary science and philosophical reflection on science. A separate, not simple methodological/ metaphilosophical problem is how to use the data of science in the sphere of essentially philosophical reflection. This requires translating the theses of science into 
language and terminology appropriate for philosophical considerations. However, this is a separate issue which is a methodological problem in itself.

6. Analyzing contemporary providence models, Professor Łukasiewicz pays particular attention to the model in which eternal God and the occurrence of chance, as well as probabilistic understanding of the states of the world, coexist. Here we have a recognition of God's omnipotence and at the same time the acceptance of the occurrence of chance, which would be, as such, known to God. As the author himself points out, in relation to this issue there are clear traces of Anselm's inspirations $(D P, 22-23)$. What is more, such inspirations, without some metaphilosophical issues, seem quite close to Łukasiewicz. These issues will be dealt with in the following chapter.

III. Analyses concerning various forms of contemporary theism, and especially, what is of particular interest to us, so-called probabilistic theism, are connected with the author's adoption of certain assumptions concerning the understanding of freedom, causality, time and suffering $(D P, 265 \mathrm{ff}$.). Here are these initial assumptions and their brief descriptions:

Freedom - an action referred to as a free action when there is a possibility to choose an alternative option,

Causality - in the work under discussion it is understood in such a way that it is supposed to be transitive,

Time - understood asymmetrically,

Suffering and evil —it is assumed that any suffering, in particular undeserved suffering (pointless and/or severe) is evil.

According to the author, our intuitions concerning the world also indicate the occurrence of random, unplanned phenomena. The conditions indicated above, if probabilistic theism is omitted, for the time being, are fulfilled to the highest degree by open theism, and to the lowest degree by classical theism. In this context, the probabilistic theism, which can be treated initially as a certain original mutation of open theism, is today considered. It seems to fulfill these intuitions concerning the world, which are indicated in the four points above, to the highest degree. 
Probabilistic theism is a theistic position, non-reducible to other positions, whose main inspirations and premises are drawn from contemporary natural sciences $(D P, 266) .{ }^{12}$ It has the following features:

A. On a metaphysical level, the following are assumed here: The creation of the world by God who has attributes of omnipotence, omniscience, and perfect goodness. Let us add that the terms "probabilism" and "probabilistic" refer here to the mechanisms of the world, not to the existence of a divine being.

B. A limited understanding of divine omnipotence is assumed.

C. Theism of this type questions the thesis on the existence of Divine providence, understood as the detailed or specific care of every element in the collection of existing entities $(D P, 268)$.

D. The existence of random (chance) phenomena is also accepted.

E. The problem of evil in this perspective appears and is solved in a specific way.

Let us now look in more detail at these several theses to characterize and subject them to a critical (sometimes) discussion.

A. As for the act of creation, this classically understood theism accepts the existence of God the Creator with certain attributes, of which one of the key ones is omnipotence. ${ }^{13}$ In the perspective of probabilistic theism, creation by God can be understood as creatio ex nihilo, where a mechanism containing one's own creative potential is created ( $D P, 295 \mathrm{ff}$.). The Divine creator achieves his goals not only by creating every element of the world but also by chance, which yet leads to order on higher levels. The existence of this created universe is sustained by God (creatio continua). In the work of creation, God does not have to act deterministically, because "Chance is part of God's intention and plan, it is an instrument of providence" $(D P, 296)$. To this attractive for many people vision, a human being is also introduced as a co-creator, by its own adequate actions ( $D P, 308 \mathrm{ff}$.). It is also said that in the created world we are dealing with something that can be described as a dialogue between God and man ( $D P, 327 \mathrm{ff}$.). In this respect, I have doubts about the possibilities of natural theology, with regard to the question of

\footnotetext{
${ }^{12}$ I omit the author's important reflections on certain precursor positions to theism or, more broadly, to the probabilistic theory $(D P, 271-75)$.

${ }^{13}$ Theism can be understood in short as: “... belief in one God, the Creator, who is infinite, selfexistent, incorporeal, eternal, ... perfect, omniscient and omnipotent." See Huw P. Owen, Concepts of Deity (London: Macmillan, 1971), 1. We should bear in mind that the term "theism" began to function in the seventeenth century in a specific polemical context, in contrast to atheism and deism and later also to pantheism.
} 
more detailed characteristics of this dialogue. Anyway, if one wants to talk about such a dialogue responsibly, one has to show more closely and precisely what this dialogue should consist of. I do not exclude in advance that such an indication is possible, but something more should be said about it in the context of natural theology. Perhaps, at this point, the analytical philosopher can refer to the inspiration of what we call the continental philosophy, or to the help of literature, or other sources? However, this issue would require further study. Such a solution involving the analytical philosopher reaching for works from another methodological school, in the case of the philosophy of religion, is seen by Trakakis. He says:

... I attempt to show that alternatives to analytic philosophy of religion are available, not only within the various schools of so-called Continental philosophy, but also in explicitly narrative and literary approaches that achieve greater philosophical insight than what is usually offered in the purely academic and highly professionalized settings of contemporary philosophy. ${ }^{14}$

In this case, the Australian philosopher even proposes to refer to alternative tools available to literature, or perhaps even art. However, the analytical philosopher, without rejecting this offer out of hand, must, in this case, ask about the cost of using the tools offered by literature in philosophy, because he usually distinguishes between these two domains - the sphere of philosophy and the sphere of literature, which have a different status. ${ }^{15}$

There are also some issues left unsaid. There is the problem of the so-called ontical chance $(D P, 296 \mathrm{ff}$.$) . By that, we mean here an event without a causal$ explanation. The author points out possible solutions (DP, 296-97). We are here on some fundamental level, analyzed also by metaphysics. I would be inclined to agree that perhaps we are approaching the end of explanation and a certain doubt, expressed by Roman Ingarden, as to whether metaphysics feasible with the help of human cognitive tools is possible, would find at this point, perhaps, an appropriate exemplification.

B. Omnipotence has sometimes been understood as resulting in no limitations for the person of God, and in effect, it means that God can also do what is logically impossible. Usually, Martin Luther and Descartes are mentioned as examples of philosophers (theologians) representing such a position. However, if we do not allow God to carry out contradictory actions, this leads to the adoption of narrower or broader restrictions. Dariusz Łukasiewicz discusses analyses concerning attribute

\footnotetext{
14 Trakakis, The End of Philosophy of Religion, 2.

15 Ryszard KLESzCZ, O rozumie i wartościach (Łódź: Wydawnictwo WSHE, 2009), 25-30.
} 
theology relatively broadly $(D P, 311-25)$. He points out that the representatives of probabilistic theism adopt various understandings of the limitations of omnipotence. It is specific for the representatives of this trend to include premises derived from the domain of natural science. Accepting the thesis about God's self-limitation, certain representatives of this type of theism understand the notion of omnipotence similarly to Richard Swinburne. His, that is Swinburne's, modified position seems to me worth defending. This does not mean that solution proposed by Swinburne does not give rise to various difficulties, but I think it defends itself better than competitive approaches. ${ }^{16}$ Here are its simplified characteristics, to a certain extent, subjected to some minor modifications introduced by me.

a. An omnipotent being is the one who can carry out any action (create any state of affairs) as long as it is logically possible. This understanding means that what is logically impossible is not really an action at all. In other words, God will not create square circles, married bachelors, but also will not change His own commandments. But if certain actions can only be carried out by certain beings, then further limitations must be adopted.

b. An omnipotent being is the one who is capable of creating every (accessible to them) logically possible state of affairs. ${ }^{17}$ For Swinburne, however, this definition, although devoid of the weakness we spoke of, is not entirely satisfactory. There is a difficulty in making things happen in the past. If we exclude them, it leads us to the following definition:

c. An omnipotent being is one who at the time $t$ has the ability to create every logically possible state of affairs, at the time after $t$. However, the question arises as to what to do with the logically necessary states of affairs, which leads us to the next point.

d. A being omnipotent at the time $t$ is the one who is capable of performing any logically possible, contingent state of things after $t$. This definition seems to meet the requirements of an omnipotent being that respects the laws of logic.

This approach assumes the existence of God in time, which is a contentious issue. It is possible, as I have shown elsewhere, to modify the above position so that it is not necessarily related to the temporality of God..$^{18}$ Professor Łukasiewicz, without resolving the problem definitely, observes that the thesis about the existence of God outside of time is not contradictory, and it is only right to accept his

${ }^{16}$ Richard Swinburne, The Coherence of Theism, 2nd ed. (Oxford: Oxford University Press, 1977), para. 9. I discuss the problem of omnipotence and its limitations in more detail in Ryszard KLESZCZ, "Logika, wszechmoc, Bóg," Filo-Sofija, no. 19 (2012): 37-52.

${ }^{17}$ Definition b. is slightly modified in relation to the original one, coming from Swinburne.

${ }^{18}$ Ryszard KLESzCZ, "O filozofii religii, wszechmocy Boga oraz ograniczoności naszego języka," Filo-Sofija, no. 30 (2015): 205ff. 
opinion $(D P, 317)$. Whether and to what extent this would be then consistent with various approaches to probabilistic theism does not seem quite clear to me. The whole dispute still seems to be continuous, although the reasons behind entering it are sometimes different. Some contemporary authors claim that it is mainly theological reasons that speak for full omnipotence. This is what Stanisław Judycki thinks in his monograph Bóg $i$ inne osoby. Próba z zakresu teologii filozoficznej. ${ }^{19}$ In his opinion, the idea of eternal life in relation to people, Trinitarian doctrine, or incarnation require omnipotence understood as absolute (without limits). This position, apart from other disputable fragments, leads to the troublesome claim that what would be metaphysically possible could be (sometimes) logically impossible. ${ }^{20}$

C. The probabilistic theism rejects the claim about God's providence understood as detailed care of each element in the collection of existing entities $(D P, 268)$. This Divine "control" does not necessarily involve interfering with the laws of nature, because it is possible to create and determine events referred to as random events in various ways. What comes into play is a coincidence or systems susceptible to huge changes caused by small stimuli $(D P, 295)$. As the author notes: "A coincidence is part of God's intention and plan, it is an instrument of providence" $(D P, 296)$. Thus, God does not achieve His goals in the world by deterministic means, but also by what we will call a chance $(D P, 309)$. In relation to man, God influences the human mind. Since this applies to every human individual, we can speak of detailed providence. Therefore, it has a limited character in the universe, not concerning the lower (quantum) sphere. At the same time this "Divine care" is not deterministic. Our freedom, in fact, is the freedom of choice between two or more alternative possibilities. In this model man is free, and this gives rise to the following question, more theological one because originating in the sphere of eschatology, namely the question of possible damnation. The fact that man can be damned, without entering into the theological debates on the subject, requires as a condition sine qua non the freedom that human action would be entitled to. At the level of natural theology, this possibility cannot be excluded. In many ways, I agree with this approach. At the same time, however, it should be noted that in order to present a comprehensive picture of human activity and freedom, it requires appropriate analyses, not only in the field of human metaphysics but also in the sciences of cognition, action, and philosophy of mind. Moreover, I also think that probabilistic theism does not provide a satisfactory answer to the question of God's extraordinary actions (miracles). It is arguable for me, not to say

\footnotetext{
${ }^{19}$ Stanisław JuDYCKI, Bóg i inne osoby. Próba z zakresu teologii filozoficznej (Poznań: W drodze, 2010), 183-99.

${ }^{20}$ About these doubts as to Judycki's position, see KLESZCZ, Logika, wszechmoc, Bóg, 46.
} 
doubtful, whether other than a symbolic understanding of miracles can be taken into consideration pursuant to this position.

D. The existence of random phenomena is accepted, which, as Professor Łukasiewicz says, occur at the quantum (behavior of atoms) or molecular level $(D P, 286 \mathrm{ff}$.$) . We can also talk about random events in the anthropological or$ historical sphere, which would be individual decisions or acts of will. Generally, on an appropriate (large) scale, such random events are supposed to result in the creation of complex structures that can be described by means of mathematical tools as a certain order. However, these various examples seem to require slightly different treatment. In the case of random events of this second type, the events from the sphere of human affairs, closer anthropological research (human metaphysics) would be required, as well as research in the field of philosophy of mind and, last but not least, research carried out within the framework of the ontology of social existence. The whole issue of order emerging from random events can, as Łukasiewicz rightly points out, lead to disputable ways of explanation, which on the metaphysical plane can take the form of atheistic or theistic syntheses. I fully agree with the author that the theistic interpretation is no less legitimate than the atheistic one, and a theist can claim that such accidental events are included in God's plan (intention). Sometimes such interpretations take the form of great syntheses. I must note, however, that I approach this kind of synthesis with a certain (albeit moderate!) degree of skepticism. When creating syntheses, if they are on the borderline of natural sciences, philosophy and theology, special competence, and methodological mastery are needed. Some proposals, in particular, known from the past, such as Teilhard de Chardin's synthesis, aroused and still raise serious doubts from positions of philosophy and theology, and science..$^{21}$ According to the author, probabilistic theism itself deals with the problem of chance, because the existence of chance may be completely consistent with the existence of God. This issue also has a clear anthropological and moral aspect which the author clearly highlights $(D P, 299 \mathrm{ff}$.). The issue of human, existential consequences of the random character of events is a problem in itself. Positive effects of the fact are the possibility of forming character and creativity, but at the same time, on the moral level, the role of randomness is assessed ambivalently. The basis for such an evaluation can be found in the Gospel and in the great literature. We also find them in works of Blaise Pascal, who points out, in a variety of contexts, that chance often governs our fates:

\footnotetext{
${ }^{21}$ Concerning the criticism of the representatives of science, see Peter MEDAWAR, "Review of Teilhard de Chardin's The Phenomenon of Man," Mind 70 (January 1961): 99-106.
} 
The most important affair in life is the choice of a calling; chance decides it. Custom makes men masons, soldiers, slaters. (Pensées, 97)

He who will know fully the vanity of man has only to consider the causes and effects of love. The cause is a je ne sais quoi (Corneille), and the effects are dreadful. This je ne sais quoi, so small an object that we cannot recognise it, agitates a whole country, princes, armies, the entire world. (Pensées, 162)

Cleopatra's nose: had it been shorter, the whole aspect of the world would have been altered. (Pensées, 162a)

But how will chance be understood here? Maybe as a low probability of occurrence of a given event, maybe as unpredictability, maybe as having no explanation, or maybe even in a different way. Whether always in these examples, a chance, however, understood, would lead to anthropologically or morally beneficial effects, is a matter for more detailed debate. However, it can be seen, as suggested by Trakakis, that reference of the philosopher of religion to the sphere of great literature is not without foundation, although it also raises many new questions.

E. On the grounds of approaches to probabilistic theism, evil, as the author indicates, is not caused by God ( $D P, 321 \mathrm{ff}$.). What is more, it is not wanted or permitted by God. In probabilistic theism, one can also deal with anti-theistic arguments on evil ( $D P, 325 \mathrm{ff}$.). Concepts of this kind do not have to deny the reality of evil, proclaiming its privative nature. Evil is something real, but not caused by God. The fact that various kinds of evil exist is determined by the mechanics of the world. As a creator, God is responsible for everything, but not as the perpetrator of evil. The author refers to the analogy with a work of art that can evoke various reactions. However, this reaction is triggered by the work, and by, one might add, its interpretations of the recipient. Nevertheless, whether there is an analogy between the two situations seems to me debatable. The question arises whether this concept of evil and theodicy is convincing. Without prejudging it, I shall only note that the willingness to recognize evil as something that is not a nothingness seems close to many contemporary people. Also in the field of literature, we can find interesting texts in which the authors in the face of the immensity of the evil of the 20th century do not want to accept the privative (Latin privatio), or the one that originates from the privative, concept of this evil. For this reason, this model (perhaps its outline) of the theodicy seems to hit the nerve of the contemporary man. This issue, however, is worth a more detailed analysis. 


\section{SUMMARY}

The reason for this work was the appearance of a monograph written by Professor Dariusz Łukasiewicz, titled Opatrzność Boża, wolność, przypadek. Studium $z$ analitycznej filozofii religii. In my paper I have shared my comments on selected elements of this book, especially those which describe proposals of probabilistic theism. Now, however, comes the time to express the general opinion on this work, which is an important publication on the Polish market, when considering the analytically oriented philosophy of religion. Let us express this opinion in several points:

1. The monograph deals with metaphysically and theologically significant and existentially important issues. The versatility of the work's content and its multifaceted approach to the analyzed issues is striking. The author is a philosopher, but he is extremely well versed also in the field of issues on the borderline of philosophy, science, and theology. Such knowledge is necessary to be able to deal successfully with this proposal (probabilistic theism). I would like to add that such comprehensive competence is nowadays indispensable for an analytical philosopher in general and an analytical philosopher of religion in particular. Only then does one have a chance not to omit those aspects of religion that are particularly important, without giving up the standards that an analytical philosopher adopts.

2. The difficulty of the author's tasks is also related to the fact that he often has to, in a way, extract the views of "probabilists" and interpret and reconstruct them. He usually succeeds in overcoming these difficulties.

3. As an analytical philosopher, Łukasiewicz is not afraid to sometimes use logical tools and he does so in a proper way, although it would be difficult to call him a reconstructive analytical philosopher in a strict sense of this term.

4. The author's metaphilosophical views are balanced, based on a perfect knowledge of the analytical tradition and to some extent, I believe, the phenomenological one. He does not underestimate the existential (religious) thread related to the problem of Providence. This allows us to conclude that the statement by Trakakis, referred to in the motto, should be taken as worth considering and thinking about, but cum grano salis. Not every analytical philosopher is interested in the naturalistically understood science, disregards the history of philosophy, and not every philosopher of religion does not take into account its existential themes.

5. To sum up, Łukasiewicz's monograph is an example of excellent work on the philosophy of religion (natural theology). In my opinion, the authorship of this 
book may do anyone credit, due to its methodological meticulousness, erudite richness, and exemplary standards of analytical reliability.

\section{BIBLIOGRAPHY}

Brentano, Franz K. "Die 25 habilitationsthesen (lateinisch und deutsch)." In Über die Zukunft der Philosophie, edited by Franz K. Brentano. Hamburg: Meiner, 1968.

Clarke, Desmond M., "Pascal's philosophy of science." In The Cambridge Companion to Pascal, edited by Nicolas Hammond. Cambridge: Cambridge University Press, 2003.

Harrington, Thomas M. Pascal philosophe. Une étude unitaire de la Pensée de Pascal. Paris: SEDES, 1982.

InGARDEN, Roman. Controversy over the Existence of the World. Vol. 1. Translated by Arthur Szylewicz. Frankfurt am Main: Peter Lang, 2013.

JuDYCKI, Stanisław. Bóg i inne osoby. Próba z zakresu teologii filozoficznej. Poznań: W drodze, 2010.

Khalfa, Jean. "Pascal's theory of knowledge." In The Cambridge Companion to Pascal, edited by Nicolas Hammond. Cambridge: Cambridge University Press, 2003.

KLESZCZ, Ryszard R. O rozumie $i$ wartościach. Łódź: Wydawnictwo WSHE, 2009.

KLeszCZ, Ryszard R. "Logika, wszechmoc, Bóg.” Filo-Sofija, no. 19 (2012): 37-52.

KLESZCZ, Ryszard R. "Błażeja Pascala refleksja nad poznaniem.” In Księga pamiątkowa Marianowi Przełęckiemu w darze na 90-lecie urodzin, edited by Anna Brożek and Jacek J. Jadacki, 234-52. Lublin: Norbertinum, 2014.

KLESZCZ, Ryszard R. "O filozofii religii, wszechmocy Boga oraz ograniczoności naszego języka." Filo-Sofija 15, no. 3 (2015): 199-214.

Levy, Neil. "Analytic and Continental Philosophy: Explaining the Differences." Metaphilosophy 34, no. 3 (2003): 284-304.

ŁUKASIEWICZ, Dariusz. Opatrzność Boża, wolność, przypadek. Studium z analitycznej filozofii religii. Poznań: W drodze, 2014.

MedaWAR, Peter B. "Review of Teilhard de Chardin's The Phenomenon of Man." Mind 70 (January 1961): 99-106.

Owen, Huw P. Concepts of Deity. London, Macmillan, 1971.

Pascal, Blaise. Pascal's Pensées. Introduction by T. S. Eliot. New York: E. P. Dutton \& Co., 1958.

Plantinga, Alvin. "God and Analogy." In The Analytic Theist. An Alvin Plantinga Reader, edited by James F. Sennett. Grand Rapids, MI: Eerdmans, 1998.

Popper, Karl R. The Logic of Scientific Discovery. London: Routledge Classics, 2002.

Sennett, James F., ed. The Analytic Theist. An Alvin Plantinga Reader. Grand Rapids, MI: Eerdmans, 1998.

Swinburne, Richard. The Coherence of Theism. Rev. ed. Oxford: Oxford University Press, 1993. First published 1977.

TrakaKis, Nick. The End of Philosophy of Religion. London-New York: Continuum, 2008. 


\title{
THE CHANCE AND THE DIVINE PROVIDENCE. METHODOLOGICAL NOTES WITH PASCAL IN THE BACKGROUND
}

\author{
S u m m a r y
}

According to the author of this paper, the analytical philosophy of religion should not be closed to other spheres of culture and ignore or disregard the achievements of others, both past and contemporary philosophical currents. An analytical philosopher, including an analytical philosopher of religion, can therefore seek inspiration also outside the sphere of analytical philosophy. At the same time, this does not mean that an analytical philosopher is to disregard natural sciences or not to care about the precision of language and the right arguments. The concern for linguistic precision and the application of appropriate argumentation are crucial for the identity of the analytical philosophy. This article, taking into account the indicated metaphilosophical attitude, is devoted to a critical discussion about some of the problems raised by Professor Dariusz Łukasiewicz, in his outstanding work in the field of philosophy of religion published in Polish as Opatrzność Boża, wolność, przypadek. Studium z analitycznej filozofii religii.

Keywords: analytical philosophy vs continental philosophy; analytical philosophy of religion; analytical philosophy and other spheres of culture; Divine Providence and chance; Providence and freedom; Dariusz Łukasiewicz.

\section{PRZYPADEK I OPATRZNOŚĆ BOŻA. UWAGI METODOLOGICZNE Z PASCALEM W DALSZYM TLE \\ Streszczenie}

Wedle autora tego artykułu, analityczna filozofia religii nie powinna być zamknięta dla innych sfer kultury i ignorować lub lekceważyć osiągnięć innych, zarówno przeszłych, jak i współczesnych prądów filozoficznych. Filozof analityczny, w tym analityczny filozof religii, może zatem szukać inspiracji również poza sferą filozofii analitycznej. Jednocześnie nie oznacza to, że filozof analityczny ma lekceważyć nauki przyrodnicze lub nie troszczyć się o precyzję języka i właściwe argumenty. Troska o precyzję językową i stosowanie odpowiednej argumentacji ma kluczowe znaczenie dla tożsamości filozofii analitycznej. Ten artykuł, biorąc pod uwagę wskazane nastawienie metafilozoficzne, poświęcony jest krytycznej dyskusji na temat niektórych problemów poruszonych przez prof. Dariusza Łukasiewicza, w jego wybitnej pracy w dziedzinie filozofii religii, noszącej tytuł Opatrzność Boża, wolność, przypadek. Studium z analitycznej filozofii religii.

Słowa kluczowe: filozofia analityczna a filozofia kontynentalna; analityczna filozofia religii; filozofia analityczna a inne sfery kultury; Opatrzność Boża i przypadek; Opatrzność i wolność; Dariusz Łukasiewicz. 